The aim of our study was to detect the expression of Ku80 in primary central nervous system lymphoma and to evaluate the relationship between Ku80 expression level and clinical outcomes. Thirty-eight patients with primary central nervous system lymphoma (PCNSL) were included in this retrospective study. The expression of Ku80 in tumor samples was determined by immunohistochemistry. One thousand neoplastic cells per specimen were counted. The expression levels were compared with the clinical data and statistically analyzed. The results of this study show that the expression of Ku80 can be found in the majority of PCNSLs. The mean expression level of Ku80 in 38 PCNSL is $64.1 \pm 24.5$. A significant difference in Ku80 expression could be found between the age $<65$ years group and age $\geq 65$ years group $(P=0.006)$. Kaplan-Meier analysis revealed that patients who showed a high Ku80 expression had a significantly shorter median survival time (MST) than patients who had low Ku80 expression $(P=0.036)$. Patients' age, tumor location, and treatment protocol were significantly related to prognosis in PCNSL $(P<0.05)$. The expression of Ku80 was observed in the majority of PCNSLs. Ku80 was a predictive factor for survival in this study. In addition to Ku80, other clinical variables including age, tumor location and therapeutic protocol are correlated significantly with overall survival.

Key words: Ku80, primary CNS lymphoma, immunohistochemistry, prognostic factor.

\section{The potential role of Ku80 in primary central nervous system lymphoma as a prognostic factor}

\author{
Xinwei $\mathrm{Li}^{1^{*}}$, Xinjia He${ }^{2^{*}}$, Xueying $\mathrm{Xu}^{3}$, Zhengfei Song ${ }^{1}$, Chong Qian ${ }^{1}$, Jin Wang ${ }^{1}$, \\ Yirong Wang ${ }^{1}$ \\ 1Department of Neurosurgery, Sir Run Run Shaw Hospital, The Affiliated Hospital \\ of Medical College, Zhejiang University, Hangzhou, P.R. China \\ 2Department of Oncology, The Affitiated Hospital of Medical College, Qingdao \\ University, Qingdao 266003, P.R. China \\ 3Operative Department, Sir Run Run Shaw Hospital, The Affiliated Hospital of Medical \\ College, Zhejiang University, Hangzhou, P.R. China
}

${ }^{*}$ Equal contributors

\section{Introduction}

Primary central nervous system lymphoma has been recently paid more attention especially for its increasing incidence, unsatisfactory therapy and poor prognosis. Radiotherapy and/or chemotherapy are still the most important methods to treat primary central nervous system lymphoma (PCNSL). Ku80, as a DNA repair protein, plays a key role in multiple nuclear processes against ionizing radiation which determine radiosensitivity $[1,2]$. The aim of our study was to detect the expression of Ku80 in PCNSL by immunohistochemical staining to evaluate the relationship between Ku80 expression level and clinical outcomes, and thus to determine whether this immunophenotype is a prognostic factors in PCNSL. It may be a new marker for anticipating curative effects. An alternative therapeutic approach to improving radiotherapeutic effects might be found.

\section{Material and methods}

\section{Patients and tissue samples}

Patients were eligible for this study if they had been diagnosed with PCNSL. Patient selection criteria for this study were as follows: (1) Histological characteristics of these cases fulfilled the criteria of the World Health Organization criteria of lymphoid neoplasms for PCNSL, (2) Patients were required to have a life expectancy greater than 1 month, with detailed clinical data at diagnosis and therapy and during follow-up. Between May 1995 and January 2009, there were 38 patients with a new histological diagnosis of PCNSL enrolled in this study in the Department of Neurosurgery, Sir Run Run Shaw Hospital, Zhejiang University. Their histological characteristics were diffuse large B cell lymphoma. Clinical follow-up was obtained until July 15, 2009, or until death or loss to follow-up. Treatment of patients varied, depending on individual conditions, the stage of the disease, date of diagnosis, institution, and health conditions. All patients were followed up postoperatively at three-month intervals or when recurrence was suspected.

\section{Immunohistochemistry}

Normal tonsil tissues obtained served as a normal control sample. A dilution of $1: 200$ was determined as the optimal dilution. Formalin-fixed, paraffin-embedded sections (3- $\mu \mathrm{m}$ thick) were dewaxed in xylene and rehydrated by passage through a graded ethanol series, then the slides were transferred to the full pressure cooker with antigen retrieval buffer for $3 \mathrm{~min}$ utes. Endogenous peroxidases were blocked with $3 \%$ hydrogen peroxide for 
10 minutes. $100 \mu$ l of prepared primary antibody $(1: 200$ dilution) was added. Anti-Ku80 mouse monoclonal antibody was incubated at room temperature for 30 minutes. The secondary antibody was anti-mouse and rabbit Histofine. The slides were counterstained with hematoxylin and finally mounted using a drop of Aquatex.

\section{Evaluation of results and statistical analysis}

A neuropathologist without prior knowledge of the patients' clinical outcomes investigated all histological specimens. Each tumor was evaluated for this gene protein and given the percentage of positive cells. One thousand neoplastic cells per specimen were evaluated at $\times 400$ magnification and the ratio (\%) of Ku80. On the basis of the ratio of positive cells, these tumors were defined as showing low Ku80 expression when there were no or fewer than $50 \%$ positive cells, and high expression when the positive rate was more than $50 \%$ [3].

Progression-free survival (PFS) was evaluated from the first day of treatment to relapse, progression or death, or to the last date of follow-up, and overall survival (OS) was calculated from the first day of treatment of the tumor to death for any reason or to the last date of follow-up. A descriptive study of all the variables was carried out. Expression of Ku80 between subgroups was analyzed by one-way ANOVA method. Kaplan-Meier methodology was applied in order to determine the effect of the different variables on survival. Parameters possibly correlated with disease progression and survival were age, gender, tumor localization, surgical procedure, chemotherapy, radiotherapy and expression of Ku80 protein. These variables were estimated with their mean and $95 \%$ confidence interval. The end-point variable of interest was overall survival. $A P<0.05$ value was considered to be of statistical significance. Analyses were performed with SPSS 17.0.

\section{Results}

\section{Patient characteristics and treatment}

Thirty-eight patients with PCNSL were included in this retrospective study. This group comprised 22 men and 16 women. The male : female ratio was 1.31, and age varied from 11 to 82 years (mean 62.25 years). The lymphomas were located as follows: In 12 patients the tumor was in a central area such as cerebellar, brain stem thalamus, hypothalamus, para- or intra-ventricular. In 15 cases the tumor was restricted to a single lobe such as frontal, temporal, parietal, occipital lobe, and more than one cerebral lobe was affected in 11 patients.

Biopsies were taken in 20 patients via a craniotomy and stereotactic biopsy in 18 patients. Treatment of patients varied, depending on individual conditions, the stage of the disease, date of diagnosis, institution, patients' intentions and health conditions. Based on these factors, 6 patients accepted HD-MTX (high-dose methotrexate)-based, multi-agent chemotherapy and 7 patients were treated with sole radiotherapy. Nineteen patients with PCNSL underwent both chemotherapy and radiotherapy whereas no adjuvant therapy was applied in 6 patients. Twenty-six patients underwent hyperfractionated whole-brain radiotherapy (WBRT) with 40-
50 Gy (2 Gy/day), which is considered equivalent to conventional irradiation with 20 fractions of 2 Gy, total 40 Gy. Among them, an additional 6-10 Gy boost to gross was performed. Twelve patients did not have any radiotherapy because of patients' intention and/or family reason. The follow-up varied from 1 month to 145 months. It was terminated at death for any reason or the last date of follow-up. The mean overall survival (OS) was 28.5 months, and the mean PFS was 28.2 months (range 0-145 months).

\section{Ku80 expression in primary central nervous system lymphoma}

The absolute expression level of Ku80 in all groups classified according to variables were analyzed by one-way ANOVA method and listed in Table 1 . There was found considerable variability in Ku80 expression level, ranging between $7.4 \%$ and $95.8 \%$ in PCNSL, mean $64.1 \%$. Fifteen tumor samples demonstrated low Ku80 staining (positive rate < 50\%, mean $31.9 \pm 11.9 \%$ ) (Fig. 1A), and 23 tumor samples demonstrated high Ku80 expression (positive rate $>50 \%$, mean 78.2 $\pm 11.8 \%$ ) (Fig. 1B).

The Ku80 expression level in PCNSL did not correlate with gender or location. No statistically significant correlation was found between age of patients and Ku80 expression

Table 1. Expression of Ku80 analyzed by one-way ANOVA method

\begin{tabular}{|c|c|c|c|}
\hline Variables & Ku80 (mean \pm SD) & Ku80 95\% Cl & $p$ value \\
\hline Overall & $64.1 \pm 24.5$ & $57.0-71.1$ & \\
\hline $\begin{array}{l}\text { Sex }(n) \\
\text { male } \\
\text { female }\end{array}$ & $\begin{array}{l}68.6 \pm 23.4 \\
58.8 \pm 25.2\end{array}$ & $\begin{array}{c}59.1-78.1 \\
47.9-69.7\end{array}$ & 0.165 \\
\hline $\begin{array}{l}\text { Age } \\
\quad<65 \\
\geq 65\end{array}$ & $\begin{array}{l}57.1 \pm 26.1 \\
70.2 \pm 21.7\end{array}$ & $\begin{array}{l}45.9-68.4 \\
61.3-78.9\end{array}$ & 0.063 \\
\hline $\begin{array}{l}\text { Tumor location } \\
\text { single lobe } \\
\text { central area } \\
\text { multiple lobes } \\
\text { others }\end{array}$ & $\begin{array}{l}59.6 \pm 28.5 \\
63.7 \pm 23.3 \\
76.4 \pm 15.4 \\
54.1 \pm 25.3\end{array}$ & $\begin{array}{l}44.9-74.2 \\
47.9-79.3 \\
67.0-85.7 \\
32.9-75.2\end{array}$ & 0.160 \\
\hline $\begin{array}{l}\text { Surgical approach } \\
\text { biopsy } \\
\text { craniotomy }\end{array}$ & $\begin{array}{l}62.1 \pm 25.5 \\
66.9 \pm 23.5\end{array}$ & $\begin{array}{l}52.4-71.8 \\
55.9-77.9\end{array}$ & 0.507 \\
\hline $\begin{array}{l}\text { Treatment } \\
\text { chemotherapy } \\
\text { radiotherapy } \\
\text { radiochemotherapy } \\
\text { no treatment }\end{array}$ & $\begin{array}{l}71.6 \pm 25.4 \\
60.3 \pm 23.1 \\
59.1 \pm 25.0 \\
62.7 \pm 22.8\end{array}$ & $\begin{array}{c}58.5-84.6 \\
38.9-81.7 \\
47.1-71.1 \\
38.8-86.7\end{array}$ & 0.479 \\
\hline $\begin{array}{l}\text { Chemotherapy } \\
\text { yes } \\
\text { no }\end{array}$ & $\begin{array}{l}65.0 \pm 25.6 \\
61.4 \pm 22.0\end{array}$ & $\begin{array}{l}56.3-73.7 \\
48.1-74.7\end{array}$ & 0.658 \\
\hline $\begin{array}{l}\text { Radiotherapy } \\
\text { yes } \\
\text { no }\end{array}$ & $\begin{array}{l}59.4 \pm 24.0 \\
69.3 \pm 24.6\end{array}$ & $\begin{array}{l}49.7-69.1 \\
58.6-79.9\end{array}$ & 0.164 \\
\hline $\begin{array}{l}\text { Ku80 expression } \\
\text { low } \\
\text { high }\end{array}$ & $\begin{array}{l}31.9 \pm 11.9 \\
78.2 \pm 11.8\end{array}$ & $\begin{array}{l}25.3-38.5 \\
74.1-82.3\end{array}$ & \\
\hline
\end{tabular}

$\mathrm{Cl}$ - confidence interval, SD - standard deviation 

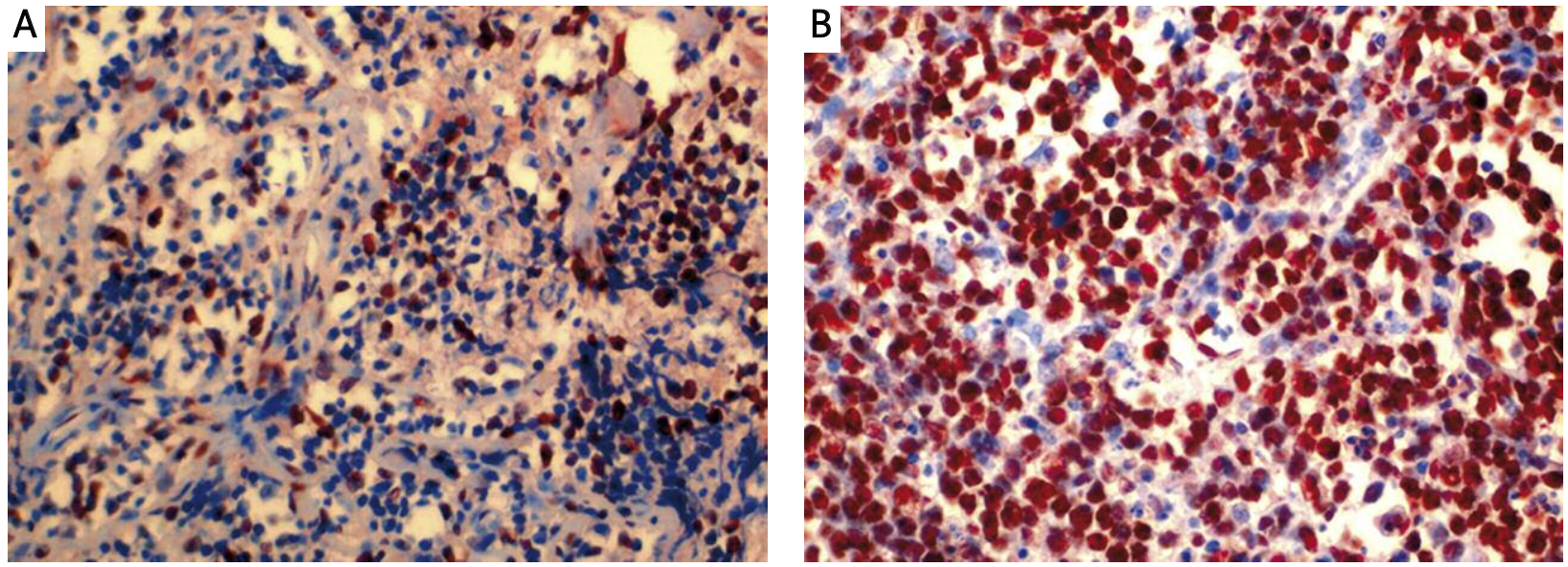

Fig. 1. Representative photomicrographs showing immunostaining for Ku80 in PCNSL samples. A) Immunohistochemical staining demonstrates the low expression of Ku80 in the PCNSL tissue, B) strong nuclear staining could be observed

$(P=0.136)$, although it seemed that the Ku80 level in the age $\geq 65$ group was usually higher than in the age $<65$ group (Table 1).

\section{Survival analysis}

Kaplan-Meier survival curves of patients were analyzed according to tumor location, surgical approach, treatment protocol, and the expression of Ku80. Patients were divided into

Table 2. Kaplan-Meier analyses for the correlation between variables and overall survival

\begin{tabular}{|c|c|c|c|c|}
\hline Variables & OS Mean & $95 \% \mathrm{Cl}$ & log-rank test & $p$ value \\
\hline $\begin{array}{l}\text { Sex } \\
\text { male } \\
\text { female }\end{array}$ & $\begin{array}{l}78.8 \\
44.0\end{array}$ & $\begin{array}{c}50.2-107.5 \\
17.8-70.3\end{array}$ & -2.677 & 0.102 \\
\hline $\begin{array}{l}\text { Age } \\
\qquad 65 \text { years } \\
\geq 65 \text { years }\end{array}$ & $\begin{array}{l}78.7 \\
45.3\end{array}$ & $\begin{array}{c}55.5-101.8 \\
17.1-73.6\end{array}$ & 6.486 & 0.011 \\
\hline $\begin{array}{l}\text { Tumor location } \\
\text { single lobe } \\
\text { multiple lobes } \\
\text { central area } \\
\text { others }\end{array}$ & $\begin{array}{c}40.1 \\
22.4 \\
71.9 \\
123.9\end{array}$ & $\begin{array}{c}20.3-59.9 \\
3.8-40.9 \\
46.7-97.2 \\
86.2-161.6\end{array}$ & 10.664 & 0.014 \\
\hline $\begin{array}{l}\text { Surgical approach } \\
\text { biopsy } \\
\text { craniotomy }\end{array}$ & $\begin{array}{l}44.4 \\
72.0\end{array}$ & $\begin{array}{l}28.1-60.7 \\
41.1-102.9\end{array}$ & 0.067 & 0.796 \\
\hline $\begin{array}{l}\text { Treatment protocol } \\
\text { chemotherapy } \\
\text { radiotherapy } \\
\text { radiochemotherapy } \\
\text { no treatment }\end{array}$ & $\begin{array}{c}62.1 \\
62.1 \\
y \\
89.2 \\
4.9\end{array}$ & $\begin{array}{c}36.3-93.3 \\
57.1-121.3 \\
18.0-106.3 \\
0.00-10.3\end{array}$ & 14.727 & 0.002 \\
\hline $\begin{array}{l}\text { Chemotherapy } \\
\text { yes } \\
\text { no }\end{array}$ & $\begin{array}{l}83.2 \\
26.0\end{array}$ & $\begin{array}{c}59.8-106.7 \\
0.00-54.6\end{array}$ & 5.245 & 0.022 \\
\hline $\begin{array}{l}\text { Radiotherapy } \\
\text { yes } \\
\text { no }\end{array}$ & $\begin{array}{l}73.5 \\
48.5\end{array}$ & $\begin{array}{l}41.9-105.1 \\
24.9-72.2\end{array}$ & 2.283 & 0.131 \\
\hline $\begin{array}{l}\text { Ku80 expression } \\
\text { low } \\
\text { high }\end{array}$ & $\begin{array}{l}80.4 \\
55.3\end{array}$ & $\begin{array}{c}53.5-107.2 \\
29.6-88.7\end{array}$ & 4.377 & 0.036 \\
\hline
\end{tabular}

a weak expression group (positive rate $<50 \%$ ) and high expression group (positive rate $\geq 50 \%$ ). These subgroups are comparable, without statistical differences in the expression level of Ku80 (Table 1, $P>0.05$ ).

PFS and OS were estimated by the Kaplan-Meier method and compared using the log-rank test (Tables 2, 3). Important tumor locations such as central areas, as expected, were found to be associated with a significantly higher risk of death

Table 3. Kaplan-Meier analyses for the correlation between variables and PFS

\begin{tabular}{|c|c|c|c|c|}
\hline Variables & PFS Mean & $95 \% \mathrm{Cl}$ & log-rank test & $p$ value \\
\hline $\begin{array}{l}\text { Sex } \\
\text { male } \\
\text { female }\end{array}$ & $\begin{array}{l}77.7 \\
46.8\end{array}$ & $\begin{array}{l}48.2-107.1 \\
20.0-73.5\end{array}$ & 2.028 & 0.154 \\
\hline $\begin{array}{l}\text { Age } \\
\qquad 65 \text { years } \\
\geq 65 \text { years }\end{array}$ & $\begin{array}{l}78.2 \\
45.4\end{array}$ & $\begin{array}{c}54.69-101.7 \\
16.2-74.4\end{array}$ & 5.902 & 0.015 \\
\hline $\begin{array}{l}\text { Tumor location } \\
\text { single lobe } \\
\text { multiple lobes } \\
\text { central area } \\
\text { others }\end{array}$ & $\begin{array}{r}40.9 \\
20.9 \\
70.1 \\
125.5\end{array}$ & $\begin{array}{c}21.2-60.6 \\
1.6-40.3 \\
44.5-95.8 \\
85.0-161.9\end{array}$ & 10.443 & 0.015 \\
\hline $\begin{array}{l}\text { Surgical approach } \\
\text { biopsy } \\
\text { craniotomy }\end{array}$ & $\begin{array}{l}45.6 \\
70.7\end{array}$ & $\begin{array}{c}29.4-61.7 \\
39.1-102.2\end{array}$ & 0.061 & 0.806 \\
\hline $\begin{array}{l}\text { Treatment protocol } \\
\text { chemotherapy } \\
\text { radiotherapy } \\
\text { radiochemotherapy } \\
\text { no treatment }\end{array}$ & $\begin{array}{c}64.7 \\
65.1 \\
89.9 \\
3.0\end{array}$ & $\begin{array}{c}35.9-93.4 \\
29.3-100.9 \\
58.0-121.9 \\
0.0-8.1\end{array}$ & 13.294 & 0.004 \\
\hline $\begin{array}{l}\text { Chemotherapy } \\
\text { yes } \\
\text { no }\end{array}$ & $\begin{array}{l}83.7 \\
25.0\end{array}$ & $\begin{array}{c}60.2-107.2 \\
0.0-54.3\end{array}$ & 4.606 & 0.032 \\
\hline $\begin{array}{l}\text { Radiotherapy } \\
\text { yes } \\
\text { no }\end{array}$ & $\begin{array}{l}74.7 \\
47.8\end{array}$ & $\begin{array}{c}42.1-107.3 \\
23.7-71.9\end{array}$ & 2.039 & 0.153 \\
\hline $\begin{array}{l}\text { Ku80 expression } \\
\text { low } \\
\text { high }\end{array}$ & $\begin{array}{l}79.2 \\
58.6\end{array}$ & $\begin{array}{l}51.7-106.7 \\
32.8-84.4\end{array}$ & 3.987 & 0.046 \\
\hline
\end{tabular}



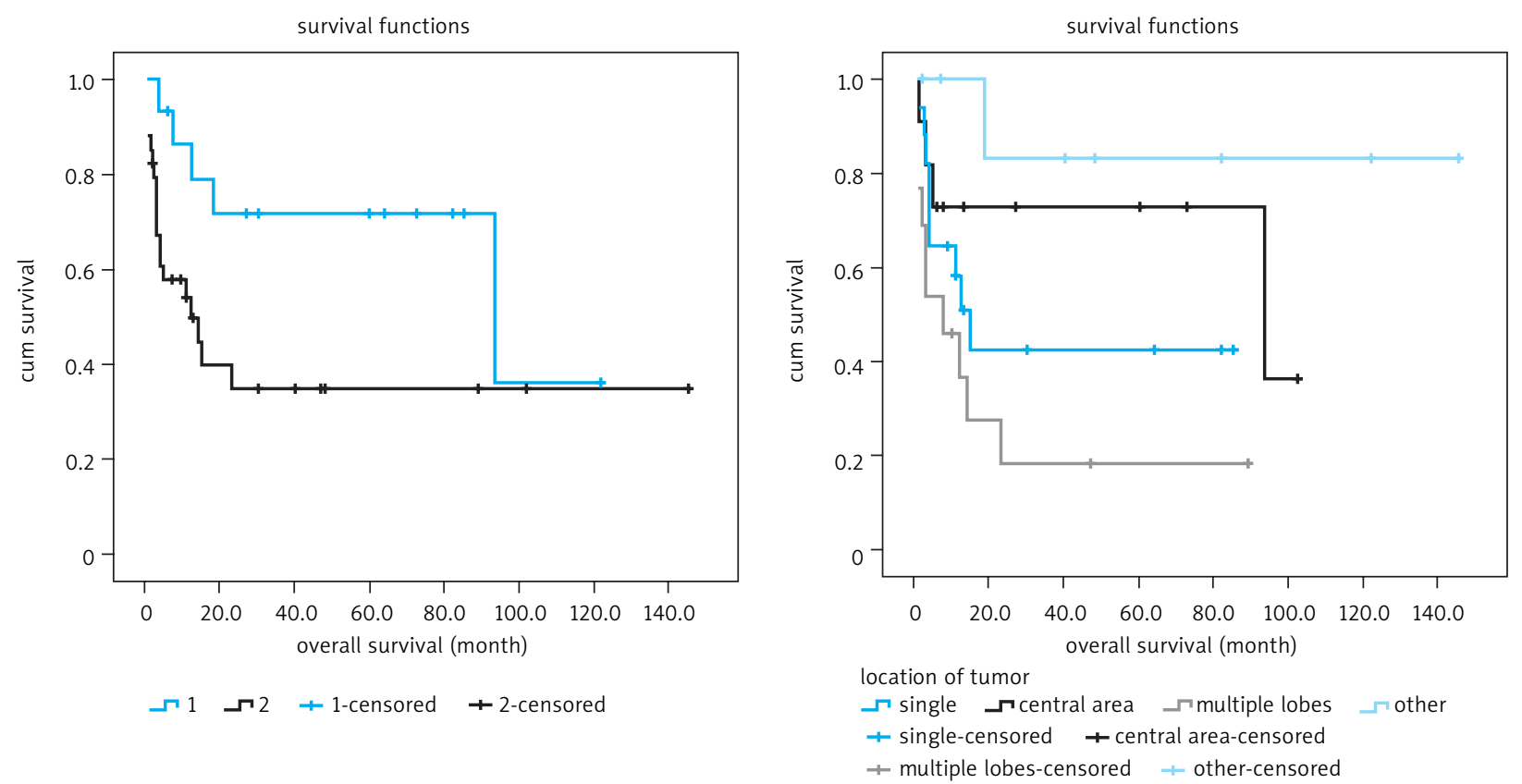

Fig. 2. Kaplan-Meier survival curves of patients with PCNSL and its impact on overall survival were analyzed according to tumor location (A) and the expression level of Ku80 (B)

$(P=0.014)$ (Fig. 2A). Similar results were obtained for patients without any adjuvant therapy compared with the group of patients who underwent chemotherapy and/or radiotherapy $(P=0.002)$. Patients older than 65 had a significantly higher risk of death (45.3 months vs. 78.6 months; $P=0.011$; log-rank test).

Kaplan-Meier analysis between variables with OS revealed that the high Ku80 expression group had a significantly shorter median survival time (MST) than the low Ku80 group (55.3 months vs. 80.4 months; $P=0.036$; log-rank test) (Fig. 2B). However, for the influence of Ku80 on survival in patients with and without radiotherapy, no statistical significance was found $(P>0.05)$. So, Ku80 may be an indicator for prognosis, but cannot predict the therapeutic effectiveness of radiotherapy.

\section{Discussion}

Primary central nervous system lymphoma has received more attention in recent years, especially for its unsatisfactory therapy and poor prognosis, resulting in increasing scientific awareness [4-6]. It is clear that its unsatisfactory therapy and poor prognosis are connected with the chemosensitivity and radiosensitivity $[7,8]$. Special attention has been paid in recent years to factors related to the molecular biological characteristics of the tumor, in an attempt to predict and improve the prognosis.

A Ku80 expression response to radiosensitivity has been observed in different cancers. It has been reported previously in cervical cancer that expression of Ku80 correlates with response to radiotherapy and survival [9]. Yin et al. stated that the interaction of C/EBPalpha with Ku70, Ku80, and poly (ADPribose) polymerase-1 increases sensitivity to DNA damage in prostate cancer cells [10]. Moeller concluded that Ku80 expression predicts failure and death following radiothera- py in head and neck cancer. Thus, Ku80 is considered as a potential prognostic marker for the prediction of radiotherapy outcome in some human cancers [11].

Despite many studies performed with established cell lines, little is known about Ku80 expression in lymphoma. The expression of Ku80 in primary central nervous system lymphoma or diffuse large B-cell lymphoma (DLBCL) has not been published. Ku70 showed relatively equal expression in different normal tissues, but Ku80 expression was somewhat more variable from tissue to tissue [12]. This study is the first to detect the expression of Ku80 in primary central nervous system lymphoma tissue in humans. The results of our exploratory study showed a wide range of expression of Ku80. A considerable Ku80 expression level in PCNSL was found with mean expression rate of $64.1 \%$. A high expression of Ku80 correlated with a poor prognosis of PCNSL. The results of Ku80 expression by gender and tumor location showed no significant difference.

We revealed that the Ku80 expression level in the old group was significantly higher than in patients under 65 . People may argue that the difference in Ku80 expression between different age groups may be due to age-dependent changes in tumor; however, no correlation was found between age of patient and Ku80 expression. It is reported that among the DSB repair proteins tested, the expression of Ku70 showed statistically significant agedependent changes in human lymphocytes, but the expression of Ku80 did not [13].

The success of DSB repair in tumor cells with high expression of Ku80 is the major cause of radiotherapy failure, leading to prolonged tumor cell survival, and tumors with a low percentage of Ku80-positive cells tend to be radiosensitive. Ku80 may be a potential prognostic marker for the prediction of radiotherapy outcome. In our study, Kaplan-Meier 
analysis revealed that patients who had high Ku80 expression had significantly shorter MST than patients who had a low Ku80 expression $(P=0.036)$. This observation suggested that Ku80 expression might be of prognostic significance in PCNSL. However, when assessing the influence of Ku80 on survival between patients with and without radiotherapy, no statistical significance was found $(P>0.05)$. So, Ku80 may be a marker for prognosis, but cannot predict the therapeutic effectiveness of radiotherapy, and of course cannot function as an indicator for radiotherapy.

Although it is supported that Ku protein expression is correlated with radiation treatment outcome [2, 9, 14, 15], there are exceptions, some showing that Ku80 expression is not correlated with radiation sensitivity [16]. A slight increase in cellular levels of Ku80 after irradiation in both human fibroblasts and lymphoblasts could be shown, while the expression of Ku70 remarkably increased [17]. This observation suggests that a radiation-resistant phenotype is determined by Ku70 expression. On the other hand, a remarkable increase of Ku80 expression, compared to Ku70 expression, occurred after irradiation [2]. This revealed that the induction of Ku80 expression by ionizing radiation may be a key step in radiation resistance. In our study Ku80 levels were detected to correlate significantly with OS, but no significant relation was found between radiotherapy and outcome. This observation supports Kasten-Pisula's results showing that Ku80 expression is not correlated with radiation sensitivity [8]. It may be one explanation that Ku80 plays a role in the repair of DNA ends by non-homologous end joining (NHEJ) cooperating with other compounds such as Ku70, DNA-PKCS, Xrcc4, DNA ligase IV and others. The other explanation is that the expression and functions of Ku80 may vary widely in various tumors.

Age and performance status (PS) are two universally accepted prognostic factors according to many authors [18-21]. It is not surprising that age is a prognostic factor as expected in this study. In our survival analysis, the expression of Ku80 was considered as an important predictor. In addition to Ku80 and age, this study reported an independent prognostic role of the involvement of location of the tumor in PCNSL patients. In fact, the involvement of periventricular regions, basal ganglia, brainstem, and/or cerebellum was associated with a poor prognosis. Treatment protocol played a prognostic role independent of age and PS with statistical significance. Nevertheless, it is plausible that age and PS influenced patient's selection to receive more or less aggressive therapy such as chemotherapy combinations with radiotherapy [22]. It is concluded that patients' age and tumor location are factors to predict prognosis in patients with PCNSL.

In conclusion, it is the first time that expression of Ku80 proteins in PCNSL has been detected with an immunohistochemical method. The expression of Ku80 was observed in the majority of PCNSLs. Ku80 was a prognostic factor in this study, but cannot predict the therapeutic effectiveness of radiotherapy. In addition to Ku80, other clinical variables including age, tumor location and therapeutic protocol are correlated significantly with overall survival. The role of these variables and the clinical relevance deserve to be assessed in further studies.
We are grateful to the Research Project of Department of Education, Zhejiang Province (No. N20100667) for financial help.

\section{References}

1. Ye J, Ren Z, Gu Q, Wang L, Wang J. Ku80 is differentially expressed in human lung carcinomas and upregulated in response to irradiation in mice. DNA Cell Biol 2011; 30: 987-94.

2. Chang HW, Kim SY, Yi SL, et al. Expression of Ku80 correlates with sensitivities to radiation in cancer cell lines of the head and neck. Oral Oncol 2006; 42: 979-86.

3. Wilson CR, Davidson SE, Margison GP, Jackson SP, Hendry JH, West CM. Expression of Ku70 correlates with survival in carcinoma of the cervix. Br J Cancer 2000; 83: 1702-6.

4. Bhagavathi S, Wilson JD. Primary central nervous system lymphoma. Arch Pathol Lab Med 2008; 132: 1830-4.

5. Mohile NA, Abrey LE. Primary central nervous system lymphoma. Neurol Clin 2007; 25: 1193-207.

6. Shibamoto Y, Ogino H, Suzuki G, et al. Primary central nervous system lymphoma in Japan: changes in clinical features, treatment, and prognosis during 1985-2004. Neuro Oncol 2008; 10: 560-8.

7. Verbeek B, Southgate TD, Gilham DE, Margison GP. O6-Methylguanine-DNA methyltransferase inactivation and chemotherapy. Br Med Bull 2008; 85: 17-33.

8. Rubenstein J, Ferreri AJ, Pittaluga S. Primary lymphoma of the central nervous system: epidemiology, pathology and current approaches to diagnosis, prognosis and treatment. Leuk Lymphoma 2008; 49 Suppl 1: 43-51.

9. Harima Y, Sawada S, Miyazaki Y, et al. Expression of Ku80 in cervical cancer correlates with response to radiotherapy and survival. Am J Clin Oncol 2003; 26: e80-5.

10. Yin $\mathrm{H}$, Glass J. In prostate cancer cells the interaction of C/EBPalpha with Ku70, Ku80, and poly(ADP-ribose) polymerase-1 increases sensitivity to DNA damage. J Biol Chem 2006; 281: 11496-505.

11. Moeller BJ, Yordy JS, Williams MD, et al. DNA repair biomarker profiling of head and neck cancer: Ku80 expression predicts locoregional failure and death following radiotherapy. Clin Cancer Res 2011; 17: 2035-43.

12. Chen TY, Chen JS, Su WC, Wu MS, Tsao CJ. Expression of DNA repair gene Ku80 in lymphoid neoplasm. Eur J Haematol 2005; 74: 481-8.

13. Ju YJ, Lee KH, Park JE, et al. Decreased expression of DNA repair proteins Ku70 and Mre11 is associated with aging and may contribute to the cellular senescence. Exp Mol Med 2006; 38: 686-93.

14. Friesland S, Kanter-Lewensohn L, Tell R, Munck-Wikland E, Lewensohn R, Nilsson A. Expression of Ku86 confers favorable outcome of tonsillar carcinoma treated with radiotherapy. Head Neck 2003; 25: 313-21.

15. Lee SW, Cho KJ, Park JH, et al. Expressions of Ku70 and DNA-PKCS as prognostic indicators of local control in nasopharyngeal carcinoma. Int J Radiat Oncol Biol Phys 2005; 62: 1451-7.

16. Kasten-Pisula U, Vronskaja S, Overgaard J, Dikomey E. In normal human fibroblasts variation in DSB repair capacity cannot be ascribed to radiation-induced changes in the localisation, expression or activity of major NHEJ proteins. Radiother Oncol 2008; 86: 321-8.

17. Brown KD, Lataxes TA, Shangary S, Mannino JL, Giardina JF, Chen J, Baskaran $\mathrm{R}$. Ionizing radiation exposure results in up-regulation of Ku70 via a p53/ataxia-telangiectasia-mutated protein-dependent mechanism. J Biol Chem 2000; 275: 6651-6.

18. A predictive model for aggressive non-Hodgkin's lymphoma. The International Non-Hodgkin's Lymphoma Prognostic Factors Project. N Engl Jed 1993; 329: 987-94.

19. Corry J, Smith JG, Wirth A, Quong G, Liew KH. Primary central nervous system lymphoma: age and performance status are more important than treatment modality. Int J Radiat Oncol Biol Phys 1998; 41: 615-20. 
20. Michalski JM, Garcia DM, Kase E, Grigsby PW, Simpson JR. Primary central nervous system lymphoma: analysis of prognostic variables and patterns of treatment failure. Radiology 1990; 176: 855-60.

21. Abrey LE, Ben-Porat L, Panageas KS, et al. Primary central nervous system lymphoma: the Memorial Sloan-Kettering Cancer Center prognostic model. J Clin Oncol 2006; 24: 5711-5.

22. Ferreri AJ, Blay JY, Reni M, et al. Prognostic scoring system for primary CNS lymphomas: the International Extranodal Lymphoma Study Group experience. J Clin Oncol 2003; 21: 266-72.

\section{Address for correspondence}

\section{Yirong Wang}

Department of Neurosurgery

Sir Run Run Shaw Hospital

The Affiliated Hospital of Medical College, Zhejiang University

No. 3 Qingchun East Road

Hangzhou 310016, P.R. China

tel. 86-0571-86006162

e-mail: yirongwang@yeah.net

Submitted: $\quad 6.02 .2012$

Accepted: $\quad 14.11 .2012$ 